\title{
The Roles of Information Systems in Linking Management Accounting and Financial Accounting: Empirical Evidence from Vietnam
}

\author{
Nguyen Thi Thanh Phuong ${ }^{1}$ \\ ${ }^{1}$ Thuongmai University, Hanoi, Vietnam \\ Correspondence: NGUYEN Thi Thanh Phuong, Thuongmai University, 79 Ho Tung Mau - Mai Dich - Cau Giay \\ district, Hanoi, Vietnam.
}

Received: August 23, 2017

Accepted: September 11, 2017

Online Published: September 12, 2017

doi:10.5430/afr.v6n4p87

URL: https://doi.org/10.5430/afr.v6n4p87

\begin{abstract}
This paper analyzes the role of information system in linking management accounting (MA) and financial accounting (FA). We employ a survey by focusing on Vietnam firms applying information systems to their accounting activities. The findings indicate eight roles of information system such (1) as facilitator, (2) as catalyst, (3) as motivator, (4) as enabler of linking MA and FA, (5) by decreasing the linkage costs, (6) improving the linkage quality, (7) enhancing accountant's the role, and (8) controlling the linkage between MA and FA. For managerial implications, we propose some recommendations for improving the role of information system in linking MA and FA. In the coming time, Vietnam firms should drastically improve information systems by using accounting software and enhancing their accountants' qualification.
\end{abstract}

Keywords: Financial accounting, Management accounting, Linkage, Accounting, Information system

\section{Introduction}

Accounting system constitutes an integral part in any firm's business activities. Accounting reports serve as a tool for providing management information for business administrators and financial information for the people outside the business. Currently, accounting is categorized into management accounting and financial accounting. These two accounting types are relatively closely related to each other; they all reflect accounting information, aimed at reflecting business operating results, all interested in cost revenue and movement of assets, capital.

The development of information systems today makes an important contribution to developing accounting systems. The application of modern technologies (e.g. Firm Resource Planning - ERP) enables to improve quality, ability to access and time for providing accounting information to managers, as well as to improve transaction procedures and allow firms to be flexible in managing collection and time for acknowledging collection.

For Vietnam firms, at the present time, the application of information technology to accounting system is very essential which allows unburdening accounting workload, shortening information provision time and making it convenient. All firms are aware of the necessity to apply technologies to accounting but not yet really get hold of the importance as well as the roles of information systems in the relationship between financial and management accounting.

For those reasons mentioned, we focus on the subject of "The roles of information systems in linking management accounting and financial accounting: Empirical evidence from Vietnam". We analyze the role of information systems in linking management accounting and financial accounting in firms.

\section{Theoretical Framework}

\subsection{Financial Accounting and Management Accounting}

Financial accounting and management accounting constitute an integral part of business accounting, in which, management accounting reports all the information measured, handled and provided for firm leadership. Meanwhile, financial accounting indicates the current situation of firms' capital and assets under a general form. In other words, financial accounting involves money flows in the relationships between firms and the economy. The financial accounting's results are shown in financial reports and used by firm leadership. Also, the information of financial accounting can be used by individuals and organizations outside, such as tax authority, statistical offices... (Llewellyn, 2003). 
According to the 2015 Accounting Law, management accounting involves collecting, processing, analyzing and providing economic, financial information at the management requests and economic, financial decisions within accounting units. Financial accounting involves collecting, processing, inspecting, analyzing and providing economic, financial information through financial statements for the people needing to use the information from accounting units (The 2015 Accounting Law, Clause 9, Article 3).

According to Zimmerman (2000), the ultimate goal of accounting is to control and serve the decision-making process in firms. For management accounting, control will involve system planning and behaviour control while decision-making process will include long-term strategic decisions and short-term operation decisions. In financial accounting, control deals with accounting management in which leaders have responsibility to the related parties, especially investors, to direct them to lucid decisions (Hemmer and Labro, 2008). In spite of the difference in the way to operate and the purpose of use in financial accounting and management accounting, the ultimate goal is towards making decisions and controlling.

\subsection{Roles of Information Systems}

Information systems constitute an important factor for linking management accounting and financial accounting by creating the flexibility in the information integration between the two accounting systems. In the age of developing technologies, the relationship between financial accounting and management accounting is being further strengthened thanks to the support from information systems. Information systems reduce the time necessary for handling transactions and integrating financial information. In addition, information systems also improve integrated accounting quality, from that to stimulate the interest of managers (Brazel and Dang, 2008). On the whole, information systems are a prerequisite and an essential condition for boosting the modern relationship between financial accounting and management accounting to enable managers and investors to make accurate and timely decisions (Francis, 2013).

The major roles of information systems in linking financial accounting and management accounting in firms are as follows:

- Information system is as a facilitator in linking financial accounting and management accounting. Both financial accounting and management accounting have a close relationship with accounting information in order to reflect business operating results through some criteria such as revenue, costs and movement of assets, capital. Meanwhile, both financial accounting and management accounting have close relationship in terms of information data. All financial accounting and management accounting data stem from original documents. Financial accounting reflects general information, whereas management accounting reflects detailed information. Therefore, applying information systems to business accounting system will enable accounting information to become more flexible and sufficient, making it convenient for implementing financial accounting, management accounting and linking between management accounting and financial accounting in firms (Taipaleenmäki and Ikäheimo, 2013).

- Information system is as a catalyst for linking financial accounting and management accounting. Information system enables firms to make the most of their material, intellectual and spiritual resources, thereby fostering the linkage between financial accounting and management accounting. Also, the information system allows firms to anticipate the technology trends by shortening the time of linking financial accounting and management accounting. In addition, information system speeds up collecting, applying and restoring accounting information in firms, from that to accelerate linking between financial accounting and management accounting. Through the automatic functions of information systems, accounting information can be best exploited, diversely applied, particularly, promptly restored. Automation uses multi control systems for equipment operations and other applications. Based on the relationship with in terms of accounting information, linking between financial accounting and management accounting can be sped up rapidly (Dechow and Mouritsen, 2005).

- Information system is as motivator in linking financial accounting and management accounting. As assumed by Dechow and Mouritsen (2005), when applying information systems in accounting, firms have to invest quite large money amount for the equipment and accounting human resources. This forces the firms to find how to effectively apply information systems in accounting in general for improving the accounting quality. One of the effective solutions for firms to improve the accounting quality is linking financial accounting and management accounting. So, the information system has become a driving force (or a motivator) for linking financial accounting and management accounting. 

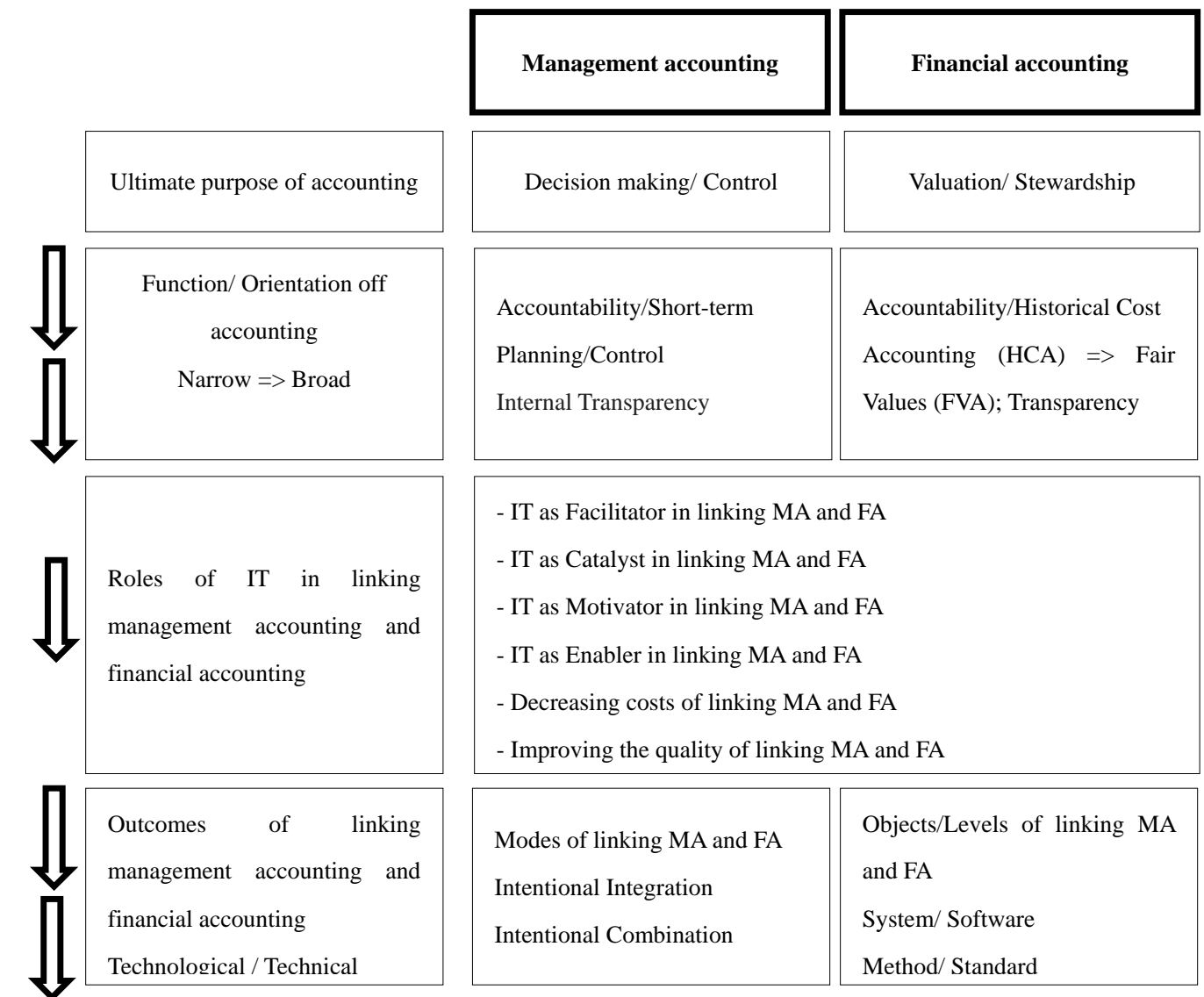

\begin{tabular}{|l|l|}
\hline Modes of linking MA and FA & $\begin{array}{l}\text { Objects/Levels of linking MA } \\
\text { Intentional Integration } \\
\text { Intentional Combination }\end{array}$ \\
& $\begin{array}{l}\text { System/ Software } \\
\text { Method/ Standard }\end{array}$ \\
\hline
\end{tabular}

$\prod \begin{aligned} & \text { Type of linking MA and FA } \\ & \text { Facilitate } \\ & \text { Catalyze } \\ & \text { Motivate }\end{aligned}$
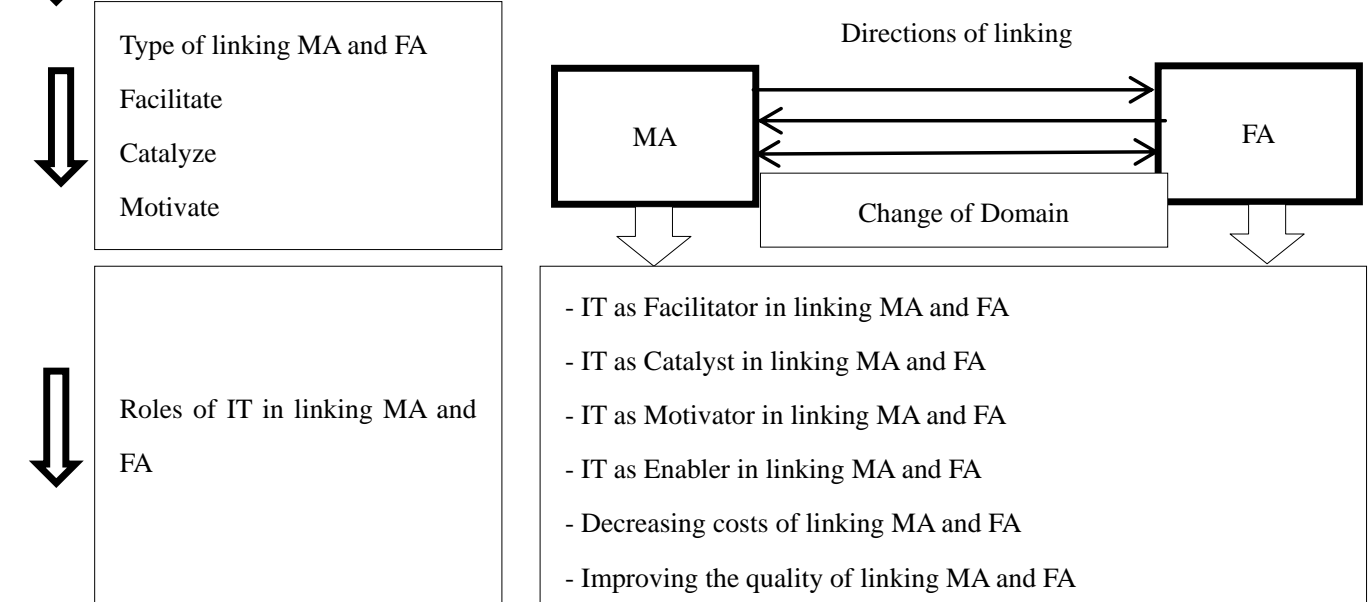

- IT as Facilitator in linking MA and FA

- IT as Catalyst in linking MA and FA

- IT as Motivator in linking MA and FA

- IT as Enabler in linking MA and FA

- Decreasing costs of linking MA and FA

- Improving the quality of linking MA and FA

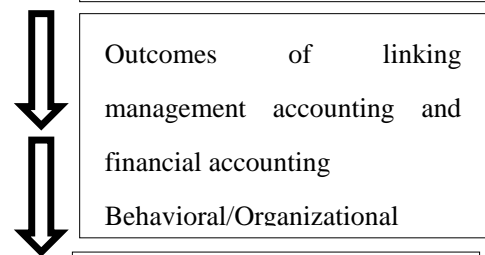

\begin{tabular}{|l|l|}
\hline Modes of linking MA and FA & Levels of linking MA and FA \\
(Un)Intentional Alignment & Function/Process \\
(Un)Intentional link & Work/Role \\
\hline
\end{tabular}
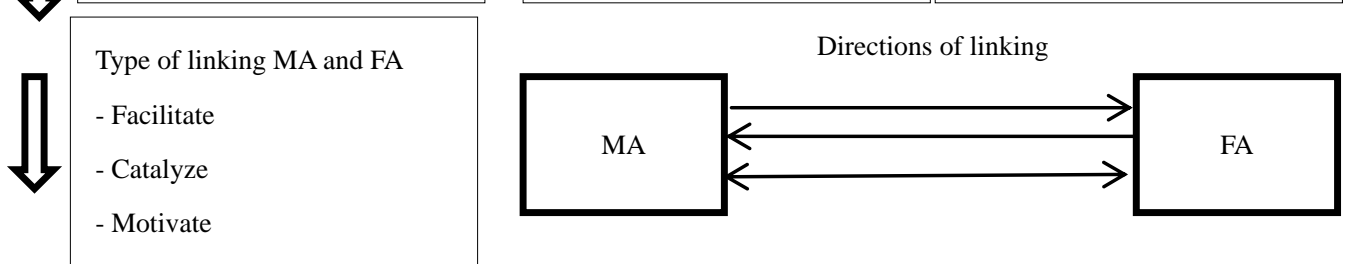

Figure 1. Roles of information system in linking financial accounting and management accounting Source: Taipaleenmäki and Ikäheimo (2013) 
- Information system is as an enabler in linking financial accounting and management accounting (Taipaleenmäki and Ikäheimo, 2013). Information systems penetrate into business activities, thus affecting the ways firms carry out financial accounting and management accounting activities. Information system application enables firms to husband the resources in the accounting sector in an effective manner. Also, information systems allow improving the accuracy of accounting information by decreasing or removing human errors in calculating. So, the benefits from information systems in accounting become an enabler in linking financial accounting and management accounting.

- Information system decreases the costs of linking financial accounting and management accounting. The application of information systems to accounting system contributes to shifting activities at high costs (information exploiting, processing, storing...) to online environment, thereby reducing costs for financial accounting and management accounting, indirectly reducing costs for linking between financial accounting and management accounting in firms. Also, applying technology to accounting systems enables firms to minimize errors during the process of collecting, processing, storing information and making reports as well. Firms therefore will minimize costs for overcoming such errors (Zsuzsanna, 2012).

- Information systems improve the quality of firms' management report and financial statement systems, thus increasing the close linkage between financial accounting and management accounting. Owing to the speed of improvement and the accuracy in the course of handling accounting information, minimizing human calculations, information systems contribute to improving the quality of linking between financial accounting and management accounting in firms (Llewellyn, 2003).

- The application of information systems in accounting systems requires accountants to improve their professional qualifications and computer skills so as to be able to control information systems and serve accounting requirements. The roles of accounts in business accounting systems in general and in linking between financial accounting and management accounting in particular therefore will be improved and have a decisive significance towards the relationship between these two accounting types (Francis, 2013).

- Information system controls linking financial accounting and management accounting through general control and application control (Zsuzsanna, 2012). Specifically, information systems generally control financial accounting and management accounting activities through controlling access, division of functions, storage and observance of procedures. Further, information systems engage in controlling business accounting system through controlling applications, controlling handling and handling results. Thanks to that, firms can partly control the linkage between financial accounting and management accounting in meeting the need for accounting information.

\section{Research Methodology}

In this research, we focus on answering the research question: What are the roles of information systems in linking financial accounting and management accounting in Vietnam firms? To find the answer of this question, we conduct a survey by focusing on Vietnam firms applying information systems to their accounting activities. For the survey, we develop a questionnaire to collect the necessary information on roles of information systems in linking financial accounting and management accounting in Vietnam firms. The questionnaire includes two parts, namely: (1) firm profile, and (2) eight roles of information systems in linking management accounting and financial accounting. We distribute the questionnaires to selected Vietnam firms after conducting a trial survey for verifying the questionnaire's reliability.

Our final sample includes 196 valid questionnaires of 196 firms, in which most of them are Joint stock (36.22\%) and Private firm (34.69\%); and they are mainly founded for 5 years (34.69\% aged 5-40 years old and $16.33 \%$ aged more than 10 years old). Also, a majority of firms in our sample operate in commerce (21.94\%) and construction (21.94\%), with average annual revenue mainly from 3 to 100 billion VND. 
Table 1. Research sample

\begin{tabular}{|c|c|c|c|c|c|}
\hline & Frequency & $\%$ & & ency & $\%$ \\
\hline Firm age & 196 & $100 \%$ & Sector & 196 & $100 \%$ \\
\hline$<1$ year old & 31 & 15.82 & Agriculture, forestry, seafood & 18 & 9.18 \\
\hline 1 - 3 years old & 35 & 17.86 & Commerce & 43 & 21.94 \\
\hline $3-5$ years old & 30 & 15.31 & Service & 39 & 19.90 \\
\hline $5-10$ years old & 68 & 34.69 & Industry and production & 27 & 13.78 \\
\hline \multirow[t]{2}{*}{$>10$ years old } & 32 & 16.33 & Construction & 43 & 21.94 \\
\hline & & & Others: .... & 26 & 13.27 \\
\hline Firm type & 196 & $100 \%$ & Revenue & 196 & $100 \%$ \\
\hline Stated-owned firm & 22 & 11.22 & $<3$ billion dong & 13 & 6.63 \\
\hline Joint stock firm & 71 & 36.22 & 3-10 billion dong & 42 & 21.43 \\
\hline Private firm & 68 & 34.69 & $10-50$ billion dong & 65 & 33.16 \\
\hline FDI firm & 17 & 8.67 & $50-100$ billion dong & 47 & 23.98 \\
\hline Others: ... & 18 & 9.18 & $>100$ billion dong & 29 & 14.80 \\
\hline
\end{tabular}

After collecting the results, we process the data by using excel and SPSS software. For analyzing the data collected, we use descriptive analysis methods such as statistics and average points. Statistics analysis allows us observe the proportional assessments; and average points show the assessment level in average of Vietnamese firm on roles of information systems in linking management accounting and financial accounting.

\section{Research Results}

\subsection{Application of Information System in Management Accounting and Financial Accounting in Vietnam Firms}

Vietnam firms' the perception of information system's the role in management accounting and financial accounting is limited. Information system does not have an independent position in the firms. Some firms use information system in the accounting system in general but the number of ones is modest. In general, the information system is not really focused in the management accounting and financial accounting. This negatively affects the proactive management by the new mechanism and the application of management accounting information systems for making decisions as well as controlling and managing the firms (Nguyen Thi Phuong Thao, 2014).

According to the Vietnam Association of Accountants and Auditors (VAA), accounting information in the firm is mainly provided by the financial accounting information system. In essence, the information provided by financial accounting primarily serves the people outside the firm, and is collected, processed and archived in a traditional manner. Although corporate management always requires the application of accounting information, it does not become an independent system in the firm.

The current situation is derived from various factors. In particular, Vietnam firms' the understanding of organization and management under the market mechanism is limited. This affects the application of information system to management accounting and financial accounting in the firms (Nguyen Thi Phuong Thao, 2014).

In the recent years, the parallel application of management accounting and financial accounting has been increasingly focused. This problem becomes urgent when Vietnam firms need to improve their management quality and increase their competitiveness in the integration process. At present, most Vietnam firms apply management accounting and financial accounting in parallel. Managerial accounting information for decision making has somewhat met the information needs for corporate internal management (La Thi Thu, 2014).

However, accounting system in Vietnam firms, especially small and medium firms are relatively simple by not paying attention to effective exploitation of information, and not creating the connection between financial accounting and management accounting. A large number of firms nowadays use accounting management but the accounting report is incomplete, the content is simple and discrete. Moreover, the firms have not built up their own set of indicators on revenue, costs and profit, but they rely on their financial statements to make decisions (Nguyen Thi Phuong Thao, 2014). 
In general, Vietnam firms are still weak in applying the information system to their accounting system for linking financial accounting and management accounting. Most firms now only spend money to buy accounting software without discussing carefully in the improvement of computerization in accounting work. This leads to the resource waste (La Thi Thu, 2014).

In addition, a large number of Vietnam firms spend a lot of money to use the information system, but their resources do not meet the increasing demand of business activities in general and accounting work in particular. Management accounting and financial accounting are overlapping and unclear. This negatively affects the application of information system in management accounting and financial accounting.

\subsection{Roles of Information System in Linking Financial Accounting and Management Accounting}

According to the survey results, the majority of the firms apply information system in professional operations (42.86\%). Out of 196 firms applying information system to accounting work, 35.02\% of he firms apply in basic business activities. It can be seen that Vietnam firms in the recent years have been aware of the important role of the information system with effective implementation of financial accounting and management accounting. The survey results also show Vietnam firms' the assessment on the roles of information system in linking financial accounting and management accounting in firms. As follows:

Table 2. Survey results on the roles of information system in linking financial accounting and management accounting

\begin{tabular}{|c|c|c|c|c|c|c|c|c|c|c|c|}
\hline \multirow{2}{*}{ Indicater } & \multicolumn{2}{|c|}{ Not important } & \multicolumn{2}{|c|}{ Few important } & \multicolumn{2}{|c|}{ Considerable } & \multicolumn{2}{|c|}{ Impertant } & \multicolumn{2}{|c|}{ Very impertant } & \multirow{2}{*}{$\begin{array}{l}\text { Average } \\
\text { point/5 }\end{array}$} \\
\hline & Freque & $\%$ & Frequ. & $\%$ & Frequ. & $\%$ & Frequi. & $\%$ & Frequ. & $\%$ & \\
\hline \multicolumn{12}{|l|}{ Information system as a facilitator } \\
\hline More flexible accounting information & & & 44 & $22.45 \%$ & 60 & $30.61 \%$ & 47 & $23.98 \%$ & 45 & $22.96 \%$ & 3.47 \\
\hline More complete accounting information & & & 40 & $20.41 \%$ & 51 & $26.02 \%$ & 61 & $31.12 \%$ & 44 & $22.45 \%$ & 3.56 \\
\hline \multicolumn{12}{|l|}{ Information sysiew a a catalyst } \\
\hline Acoelerating the link throagh automation & 2 & $1.02 \%$ & 37 & $18.88 \%$ & 54 & $27.55 \%$ & 54 & $27.55 \%$ & 49 & $25.00 \%$ & 3.57 \\
\hline \multicolumn{12}{|l|}{ Information system as notivutar } \\
\hline Using effective accounting resources & 1 & $0.51 \%$ & 35 & $17.86 \%$ & 72 & $36.73 \%$ & 48 & $24.49 \%$ & 40 & $20.41 \%$ & 3.46 \\
\hline $\begin{array}{l}\text { Increasing the accuracy of accounting } \\
\text { information }\end{array}$ & & & 26 & $13.27 \%$ & 43 & $21.94 \%$ & 66 & $33.67 \%$ & 61 & $31.12 \%$ & 3.83 \\
\hline \multicolumn{12}{|l|}{ Information system as an emabler } \\
\hline Enhancing linking capability & & & 65 & $33.16 \%$ & 43 & $21.94 \%$ & 32 & $16.33 \%$ & 56 & $28.57 \%$ & 3.4 \\
\hline \multicolumn{12}{|l|}{ Decreaving costs } \\
\hline Decreasing operating costs & & & 39 & $19.90 \%$ & 43 & $21.94 \%$ & 68 & $34.69 \%$ & 46 & $23.47 \%$ & 3.62 \\
\hline Decreasing the cost of solving the problem & & & 22 & $11.22 \%$ & 15 & $7.65 \%$ & 72 & $36.73 \%$ & 87 & $44.39 \%$ & 4.14 \\
\hline \multicolumn{12}{|c|}{ Improving the guality of management nepart and finamcial statemew systems } \\
\hline $\begin{array}{l}\text { Improving the information exploitation, } \\
\text { processing and storage }\end{array}$ & & & 48 & $24.49 \%$ & 51 & $26.02 \%$ & 52 & $26.53 \%$ & 45 & $22.96 \%$ & 3.48 \\
\hline Improving accounting reporting & & & 36 & $18.37 \%$ & 43 & $21,94 \%$ & 73 & $37.24 \%$ & 44 & $22.45 \%$ & 3.64 \\
\hline \multicolumn{12}{|l|}{ Enhancing accointants' nole } \\
\hline Improving professional qualification & & & 77 & $39.29 \%$ & 67 & $34.18 \%$ & 33 & $16.84 \%$ & 19 & $9.69 \%$ & 297 \\
\hline Improving computer skills & 2 & $1.02 \%$ & $4 ?$ & $23.98 \%$ & 47 & $23.98 \%$ & 55 & $28.06 \%$ & 45 & $22,96 \%$ & 3.48 \\
\hline \multicolumn{12}{|c|}{ Controlling the linking financial accownting and management accounting } \\
\hline General control & 2 & $1.02 \%$ & 46 & $23,47 \%$ & 65 & $33.16 \%$ & 4) & $20.41 \%$ & 43 & $21.94 \%$ & 3.39 \\
\hline Application control & & & 55 & $28.06 \%$ & 56 & $28.57 \%$ & 27 & $13.78 \%$ & 58 & $29.59 \%$ & 3.45 \\
\hline
\end{tabular}

Information system is as a facilitator in linking financial accounting and management accounting: According to the survey results, the application of information system to the accounting system allows accounting information to become more flexible. This facilitates the linking of financial accounting with management accounting. As many as $46,94 \%$ of firms think that information system plays an important role in linking financial accounting with management accounting. In addition, a large proportion $(53.57 \%)$ of the firms believe that the information system plays an important role in the accounting system by allowing accounting information to become more adequate, thereby facilitating the linking financial accounting with management accounting in the firms. This result is 
consistent with the research by Taipaleenmäki and Ikäheimo (2013) on the roles of information system in facilitating the linking of financial accounting and management accounting. They found that both types of financial accounting and management accounting have a close relationship with accounting information. Meanwhile, financial accounting and management accounting have a close relationship of information data. Therefore, the application of information system to the accounting system facilitates the linking of financial accounting with the management accounting in firms.

Information system is as a catalyst for linking financial accounting and management accounting: The survey results show that more than half of Vietnam firms (52.55\%) currently assess that information system serves as a catalyst for linking financial accounting and management accounting. The automation function of information system speeds up the accounting information collection, application and storage, thereby accelerating the linking between financial accounting and management accounting. The research results support the finding of Dechow and Mouritsen (2005) that the information system serves as a catalyst for linking financial accounting and management accounting.

Information system is as a motivator in linking financial accounting and management accounting: Only 18.37\% of the firms in the survey have not recognized that the information system allows them to use the efficient accounting resources, thus linking financial accounting and management accounting in the firms. In addition, a relatively large number (64.79\%) of the firms believe that information system increases the accuracy of accounting information by promoting the linking between management accounting and financial accounting in their firms.

Information system is as an enabler in linking financial accounting and management accounting: The survey results indicate as many as $33.16 \%$ of the firms have not realized information system's the roles in improving the ability to link financial accounting and management accounting. These firms think that the information system has not influenced the way firms carry out financial accounting and management accounting in their firms, thus not enhancing the linking between management accounting and financial accounting in their firms.

Information system decreases the cost of linking financial accounting and management accounting: As many as $58.16 \%$ of the firms in the survey said that the application of information system has been very helpful for them in the accounting work by decreasing the costs of linking financial accounting and management accounting. Specially, the application of information system to the accounting system contributes to the transfer of high-cost activities (collecting, processing, and storing information) to the online ones. Notably, $81.12 \%$ of Vietnam firms think that the accounting system applied in accounting is really important in reducing the cost of linking two types of accounting in their firms. In particular, the application of information system to the accounting system allows them to minimize errors in the process of collecting, processing, storing information, and making reports, thereby minimizing the cost of resolving the problems.

Information system improves the quality of linking financial accounting and management accounting: The survey results show that information system plays an important role in improving the linking between financial accounting and management accounting in Vietnam firms. Specifically, 49.49\% of the respondents said that the information system improved the quality of linking financial accounting and management accounting in their firm by improving collecting, processing and storing the data. In addition, 59.69\% of the firms assess that information system improves the quality of linking financial accounting and management accounting in the firms by improving thier reporting and other output information.

Information system enhances accountant's the role in linking management accounting and financial accounting: According to the survey results, the information system has not significantly contributed to the improvement of accountants' professional qualifications. So, this has not contributed to enhancing the role of accountants in the linking of financial accounting and management accounting. On the contrary, up to $51.02 \%$ of Vietnam firms believe that the information system actively contributes to the improvement of the accountants' IT skills, thereby enhancing accountants' the role in linking financial accounting and management accounting.

Information system controls linking financial accounting and management accounting: The research results show that the information system contributes significantly to controlling the linking of financial accounting and management accounting. Specifically, $42.35 \%$ of the firms said that IT contributed significantly to the control of financial accounting and management accounting through general control (access control, functional division, storage control and process compliance). At the same time, $43.37 \%$ of Vietnam firms assess IT is as a contributor to controlling financial accounting and management accounting through application control (data source control, processing control, and result control). 
Thus, the survey results show that Vietnam firms are now aware of the important roles of information system in linking financial accounting and management accounting. However, Vietnam firm leaders' some perceptions are sometimes limited. In addition, in the context of the current business environment, it has not created favorable conditions for the information system to effectively promote its role in linking financial accounting and management accounting in the firms.

\section{Implications of the Results}

On the basis of the research results, the paper proposes some recommendations for improving the roles of information systems in linking financial accounting and management accounting as follows:

Firstly, Vietnam firms should drastically improve and apply information systems to accounting activity arrangement through the use of accounting software in the corporate accounting systems. Before deciding to use any application software in the corporate accounting system, should thoroughly study, survey and exchange with the supplier in a professional way about applying computerization in accounting. Vietnam firms should go deeply into their business nature, specific features of each department, section so as to establish a stable technology system which can deeply store data and analyze activities in detail of each department, production workshop... The selection of a corporate accounting system should be always regarded as a primary task, a major project to implement. In case of upgrading and changing the systems, it should be cleared up what points the former systems can meet and what are still shortcomings from that to set up professional modules as requested by firms; this must be practical at present and can meet the management requirements in the future.

Secondly, the application of information systems to accounting should be accompanied by user management fulfillment. This means that companies should clear definitions of responsibility among sections, assignment of responsibilities in accessing and managing databases as well. Each section shall be devolved different rights such as right to access, right to add, right to revise, right to delete, etc. to define clearly responsibilities, to be able to refer to financial information when errors occurring, and to reduce fraudulent behaviours in banking operations.

Thirdly, Vietnam firms should improve accounting data systems by applying information systems. In order to not lose data unexpectedly, companies should maintain storage devices in parallel when troubles occur. For major firms, a back-up system is necessary while waiting for the troubles to be overcome. Further, such systems should also be maintained on a periodical basis for the facilities and equipment and data. Firms need to have strong antivirus software regularly updated in time to detect defective, wrong, false information and external factors trying to penetrate into the systems.

Fourthly, Vietnam firms should have clear regulations on functions and rights of users so as to avoid the case of stealing data, transferring internal data to the outside. Some additional technical measures can also be applied by firms for data confidentiality: data coding, electronic signing...to ensure the linkage between financial accounting and management accounting in firms.

Fifthly, Vietnam firms should be proactive in accessing and applying the ERP system. In developed countries, applying information systems to business administration and provide information for agencies through the Enterprise Resource Planning (ERP) software is very popular. With software as such, apart from supporting banking operations, managing information, the linkage between financial accounting and management accounting will also be closer. Vietnam firms therefore should take into consideration improving the existing accounting software, applying ERP technology to meet corporate management requirements in conformity with computer skills of accountants, with the financial floor and their own financial capacity.

Sixthly, Vietnam firms should apply information systems to organizing accounting bodies with the interference between financial accounting and management accounting. To ensure the leakage between financial accounting and management accounting, Vietnam firms should apply information systems to organizing management accounting bodies combined with financial accounting in a close manner. Nevertheless, in this combination there should be clear separation, assignment of the information provision content, scope of provision as well as the relationship between financial accounting and management accounting so as to avoid overlapping, delay in handling, providing information.

\section{Concluding Remarks}

The paper focuses on studying the roles of information systems in linking financial accounting and management accounting. By summarizing the domestic and international researches, the paper highlights the eight main roles of information systems in linking financial accounting and management accounting in firms. Specifically, information system is considered as a facilitator, as a catalyst, as a motivator, as an enabler in linking financial accounting and 
management accounting. Also, it decreases the cost by improving the quality and by controlling the linking financial accounting and management accounting. Finally, it enhances the accountant's the role in linking management accounting and financial accounting.

Our survey results on 196 Vietnam firms applying information systems to accounting showed that these firms have currently been aware of the important roles of information systems in business accounting activities, especially in linking between financial accounting and management accounting. Nevertheless, some observations made by Vietnam firms' leaders were sometimes not yet deep. In addition to that, in the context the Vietnam economy and the production and business environment at present do not make it convenient for information systems to bring into play their roles in linking between financial accounting and management accounting in firms.

On the basis of the research findings, the paper proposes six recommendations for improving the roles of information systems in linking financial accounting and management accounting in Vietnam firms. Firstly, Vietnam firms should drastically improve and apply information systems to accounting activity arrangement through the use of accounting software in the corporate accounting systems. Secondly, the application of information systems to accounting should be accompanied by user management fulfillment. Thirdly, Vietnam firms should improve accounting data systems by applying information systems. Fourthly, Vietnam firms should have clear regulations on functions and rights of users so as to avoid the case of stealing data, transferring internal data to the outside. Fifthly, Vietnam firms should be proactive in accessing and applying the ERP system. Sixthly, Vietnam firms should apply information systems to organizing accounting bodies with the interference between financial accounting and management accounting.

\section{References}

Brazel Joseph F., Dang Li. (2008). The Effect of ERP System Implementations on the Management of Earnings and Earnings Release Dates. Journal of Information Systems, 22(2), 1-21. https://doi.org/10.2308/jis.2008.22.2.1

Dechow N, Mouritsen J. (2005). Enterprise resource planning systems, management control and the quest for integration. Accounting, Organizations and Society, 30(7-8), 691-733. https://doi.org/10.1016/j.aos.2004.11.004

Francis Pol C. Lim. (2013). Impact of Information Technology on Accounting Systems. Asia-pacific Journal of Multimedia Services Convergent with Art, Humanities, and Sociology, 3(2), 93-106. https://doi.org/10.14257/AJMAHS.2013.12.02

Hemmer T, Labro E. (2008). On the optimal relation between the properties of managerial and financial reporting systems. Journal of Accounting Research, 46(5), 1209-1240. https://doi.org/10.1111/j.1475-679X.2008.00303.x

Lã Thị Thu. (2014). Tổ chức thông tin kế toán trong các doanh nghiệp hiện nay. Tạp chí Tài chính số 9 năm 2014.

Llewellyn S. (2003). What counts as "theory" in qualitative management and accounting research? Introducing five levels of theorizing. Accounting, Auditing \& Accountability Journal, (16), 662-708. https://doi.org/10.1108/09513570310492344

Nguyễn Thị Phương Thảo. (2014). Xây dựng hệ thống thông tin kế toán doanh nghiệp tại Việt Nam hiện nay. Tạp chí Tài chính số 4 năm 2014.

Taipaleenmäki Jani, Ikäheimo Seppo. (2013). On the convergence of management accounting and financial accounting - the role of information technology in accounting change. International Journal of Accounting Information Systems, 14(4), 321-348. https://doi.org/10.1016/j.accinf.2013.09.003

Zimmerman J. (2000). Accounting for decision making and control. Boston: Irwin McGraw-Hill.

Zsuzsanna Tóth. (2012). The Current Role of Accounting Information Systems. Theory Methodology Practice (TMP), 8(01), 91-95. 